\title{
ARTIKKELIT
}

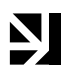

\section{Kartoittava kirjallisuuskatsaus ikääntyneiden arkikuntoutuksen ominaispiirteistä}

\author{
Satu Niskanen ${ }^{1,2,3,4}$, Leena Forma ${ }^{1,5}$, Anna-Liisa Salminen ${ }^{6}$, Anna Liisa Aho ${ }^{1}$ \\ ${ }^{1} Y$ bteiskuntatieteiden tiedekunta, Tampereen yliopisto \\ ${ }^{2}$ Voimin $O y$ \\ ${ }^{3}$ Kuntoutussäätiö \\ ${ }^{4}$ Toimintaterapeuttiliitto \\ ${ }^{5}$ Valtiotieteellinen tiedekunta, Helsingin yliopisto \\ ${ }^{6}$ Kansaneläkelaitos
}

\begin{abstract}
Arkikuntoutus on yksi kotikuntoutuksen muodoista. Kartoittavan kirjallisuuskatsauksen tarkoituksena on määritellä arkikuntoutuksen ominaispiirteet. Järjestelmällisesti toteutetun kirjallisuushaun aineisto kerättiin kuudesta tietokannasta vuosilta 2007-2018. Mukaan otettiin eri menetelmin toteutettuja tutkimuksia. Katsaukseen valitut artikkelit $(n=13)$ kartoitettiin kuvailevan synteesin avulla. Arkikuntoutuksen tavoitteet liittyivät asiakkaan toimintakyvyn ja itsenäisen suoriutumisen tukemiseen, asiakkaan terveyttä edistävien ja sairauksia ehkäisevien taitojen kehittymiseen sekä asiakkaan osallisuuden ja aktiivisuuden tukemiseen. Arkikuntoutuksen keinoina hyödynnettiin yksilöllistä arkikuntoutusjakson toteutusta, asiakkaan voimaantumisen tukemista, asiakkaan toiminnan mahdollistamista sekä käytettäviä harjoitteita. Käytännössä arkikuntoutuksessa hyödynnetään COPM- tai TARGET-arviointimenetelmiä, fyysistä toimintakykyä tukevia harjoitteita, päivittäisten toimien toistamista, toiminnan ja ympäristön muokkaamista sekä asiakkaan voimaannuttamista. Arkikuntoutuksen organisoinnissa ilmeni työnjakoon, johtamiseen ja kestoon liittyviä ominaispiirteitä, ja arkikuntoutuksen kohderyhmä määriteltiin iän, diagnoosin, toimintakyvyn sekä palvelujen käytön perusteella. Arkikuntoutuksen ominaispiirteiden määrittely sujuvoittaa viestintää ja tukee yhteisen ymmärryksen saavuttamista Suomessa kotikuntoutusmenetelmistä puhuttaessa.
\end{abstract}




\section{Johdanto}

Kuntoutuksen uudistamiskomitean määrittelee kuntoutuskäsitteen seuraavasti:"Kuntoutus on kuntoutujan tarpeista ja tavoitteista lähtevä, suunnitelmallinen prosessi, jossa kuntoutuja ylläpitää ja edistää toiminta- ja työkykyään ammattilaisten tuella. Kuntoutukseen kuuluu kuntoutujan toimintaympäristöjen kehittäminen. Kuntoutus tukee kuntoutujan ja hänen lähipiirinsä voimavaroja, itsenäistä elämää, työllistyvyyttä ja sosiaalista osallisuutta.”(Kuntoutuksen uudistamiskomitean ehdotukset kuntoutusjärjestelmän uudistamiseksi 2017, 35.) Kuntoutusta voidaan toteuttaa esimerkiksi kuntoutuslaitoksissa, palveluntuottajan tiloissa tai asiakkaan luonnollisissa toimintaympäristöissä. (Autti-Rämö ym. 2016, 69).

Arkikuntoutus on uusi, erityisesti toimintaterapeuttien sosiaali- ja terveydenhuoltoon tuoma, käsite. Arkikuntoutuksen (reablement, restorative care) käsite on käännös Norjassa käytetystä termistä hverdagsrehabilitering ja ruotsinkielisestä käsitteestä vardagsrehabilitering. Kjerstadin ja Tuntlandin (2015) mukaan arkikuntoutus on yksi kotikuntoutuksen muoto. Arkikuntoutuksella tarkoitetaan ikääntyneen omassa elinpiirissä toteutuvaa ikääntyneen omatoimisuutta tukevaa moniammatillista ja asiakaslähtöistä sekä ajallisesti rajattua kuntoutusta. Arkikuntoutus perustuu ikääntyneen määrittelemiin omatoimisuutta tukeviin kuntoutustavoitteisiin, ja ikääntyneen oma sitoutuminen sekä motivaatio ovat keskeisiä menetelmän toteutuksessa. (Kjerstad \& Tuntland 2015.) Ikääntyneille suunnattua arkikuntoutusta on hyödynnetty Australiassa, Isossa-Britanniassa, Tanskassa, Ruotsissa sekä Norjassa jo vuosia (Tuntland \& Ness 2014).

Suomessa arkikuntoutusta ei juurikaan tunneta. Suomessa on käytössä erilaisia kotikuntoutuksen muotoja, kuten Eksoten kotikuntoutus, Uudenmaan kotikuntoutus, Kukoistavan kotihoidon hankkeessa kehitetty kotikuntoutus sekä Pirkanmaan Ikäneuvo-hankkeessa kehitetyt kotikuntoutusmallit. Koti- kuntoutusmuotojen toteutuksesta on kuitenkin julkaistu vain vähän tarkkoja kuvauksia. Suomessa kotikuntoutukseen liittyvien käsitteiden käyttö on myös epäjohdonmukaista. Kotikuntoutuksesta puhuttaessa käytetään esimerkiksi käsitteitä tehostettu kotikuntoutus, arvioiva kuntoutusjakso ja moniammatillinen kotikuntoutus. Samasta kuntoutusmuodosta puhuttaessa saatetaan käyttää eri käsitteitä ja eri kuntoutusmuodoista puhuttaessa saatetaan käyttää samaa käsitettä.

Arkikuntoutuksesta on tehty useita vertaisarvioituja katsauksia, joissa on tarkasteltu arkikuntoutuksen vaikuttavuutta, (Boniface ym. 2013; Whitehead ym. 2015; Pettersson \& Iwarsson 2017), kustannus-vaikuttavuutta (Boniface ym. 2013; Cochrane ym. 2016) ja asiakkaiden kokemuksia arkikuntoutuksesta (Gregory ym. 2017). Arkikuntoutuksen toteutustavoissa on eroja, ja katsauksissa on vertailtu eri maiden arkikuntoutusten toteutusta toisiinsa (Ryburn ym. 2009; Sims-Gould ym. 2017) tai verrattu arkikuntoutusta muihin interventioihin (esim. Boniface ym. 2013; McGoldrick ym. 2017). Vaikka arkikuntoutuksesta on tehty useita tutkimuksia, sen ominaispiirteitä ei ole määritelty riittävän tarkasti (Sims-Gould ym. 2017). Tämä vaikeuttaa arkikuntoutuksen käyttöön ottamista niissä maissa, joissa arkikuntoutusta ei vielä tunneta. Jotta arkikuntoutus ja sen mahdollisuudet osana suomalaisia kuntoutuspalveluja ymmärrettäisiin, käsitteen ominaispiireet tulee määritellä. Kirjallisuuskatsauksessa keskitytään ikääntyneiden arkikuntoutukseen, koska ikääntyneet ovat arkikuntoutuksen suurin kohderyhmä.

Kirjallisuuskatsauksen tarkoituksena on jäsentää arkikuntoutuksen käsitettä ja tuottaa yksityiskohtaisempaa tietoa arkikuntoutuksen käytännön toteutuksesta. Kirjallisuuskatsauksen tarkoituksena on määritellä ikääntyneiden arkikuntoutuksen ominaispiirteet. Tutkimuksen tavoitteena on tuottaa yksityiskohtaisempaa tietoa arkikuntoutuksen ominaispiirteistä, jotta sitä voitaisiin hyödyntää ikääntyneiden kotikuntoutuksessa. Käsitteen määrit- 
tely sujuvoittaa kotikuntoutukseen liittyvää viestintää ja tukee yhteisen ymmärryksen saavuttamista Suomessa.

Tutkimuskysymys määritellään seuraavassa luvussa.

\section{Menetelmät}

Tutkimus toteutettiin kartoittavan kirjallisuuskatsauksen vaiheiden mukaisesti. Kartoittavan kirjallisuuskatsauksen vaiheet ovat: 1) Tutkimuskysymyksen määrittely, 2) Tarkoituksenmukaisten tutkimusten määrittely, 3) Tutkimusten valitseminen, 4) Aineiston kartoittaminen ja 5) Tulosten lajittelu, yhteenveto ja raportointi (Levac ym. 2010).

\section{Tutkimuskysymyksen määrittely}

Tutkimuskysymys: Mitkä ovat arkikuntoutuksen ominaispiirteet?

\section{Tarkoituksenmukaisten tutkimusten määrittely ja valitseminen}

Tutkimukseen haluttiin mukaan ainoastaan arkikuntoutusta kuvaavat julkaisut ja muita kotikuntoutusmuotoja kuvaavat julkaisut haluttiin rajata tutkimuksen ulkopuolelle. Kirjallisuuskatsauksen hakusanoina käytettiin reablement tai re-ablement tai restorative rajattuna otsikkoon tai abstraktiin sekä age tai aging tai ager tai older tai elder*ilman haunrajausta tai rajattuna abstraktihakuun. Haussa hyödynnettiin tietokantojen omia asiasanoja ja hakuajankohtana tietokannat tunnistivat asiasanat reablement tai re-ablement. Haku toteutettiin myös suomenkieliseen Medic-tietokantaan suomenkielisellä arkikuntoutus-käsitteellä, mutta arkikuntoutuksesta ei ole tehty vielä yhtään suomenkielistä vertaisarvioitua julkaisua.

Kirjallisuushaku toteutettiin järjestelmällisesti CINAHL, Medline (EBSCO), Academic Search Premier, Social Science Database sekä Sociology Collection (ProQuest) ja PsycINFO -tietokannoissa marraskuun 2017 ja tammikuun 2018 välisenä aikana. Hakua täydennettiin käsihaulla, jossa etsittiin kriteerit täyttäviä artikkeleita tietokantahaussa löytyneiden artikkeleiden lähdeluetteloista. Haku toteutettiin vuosirajauksella 2007-2018, ja jos hakukoneessa oli määriteltävissä ikäryhmä, valittiin kohderyhmäksi yli 65-vuotiaat. Sisäänottokriteerit olivat: 1) julkaisu käsittelee arkikuntoutusta, 2) julkaisu on vertaisarvioitu, 3) julkaisu on kokonaan saatavilla tai hankittavissa Tampereen yliopiston tietokantojen tai yhteyksien kautta, 4) julkaisukieli on englanti tai suomi, 5) intervention kohderyhmä ei ole ympärivuorokautisessa hoidossa ja 6) intervention kohderyhmänä ovat yli 65-vuotiaat. Mikäli tutkimuksessa käsiteltiin interventiota, joka oli suunnattu yli 65-vuotiaiden lisäksi myös nuoremmille asiakkaille, hyväksyttiin se tutkimukseen. Kirjallisuushaun eteneminen on kuvattu kuviossa 1 . Hausta ( $n=629)$ hylättiin ensin päällekkäiset julkaisut ja julkaisut, joita ei oltu vertaisarvioitu. Otsikon perusteella hylättiin julkaisut, jotka eivät liittyneet arkikuntoutukseen $(n=419)$ vaan käsittelivät esimerkiksi palauttavaa unta tai palauttavaa joogaa. Seuraavaksi luettiin viitteiden tiivistelmät $(\mathrm{n}=112)$, joista valittiin 64 julkaisua tarkempaan tarkasteluun. Luetuista kokoteksteistä analysoitavaksi valittiin 13 artikkelia. Kirjallisuuskatsaukseen valitut julkaisut on esitelty taulukossa 1.

\section{Aineiston kartoittaminen}

Aineisto kartoitettiin kuvailevan synteesin avulla. Kuvaileva synteesi noudattaa sisällönanalyysin periaatteita, mutta kirjallisuuskatsauksen yhteydessä ei tyypillisesti puhuta sisällönanalyysistä vaan kuvailevasta synteesistä (Petticrew 2001; Khan ym. 2003; Kääriäinen \& Lahtinen 2006), koska katsauksen tarkoituksena on asioiden ryhmittely eikä niinkään yleiskäsitteen muodostaminen pelkistämällä (Kyngäs ym. 2011). Kuvaileva synteesi aloitettiin poimimalla tutkimusmenetelmien kuvauksista tai 


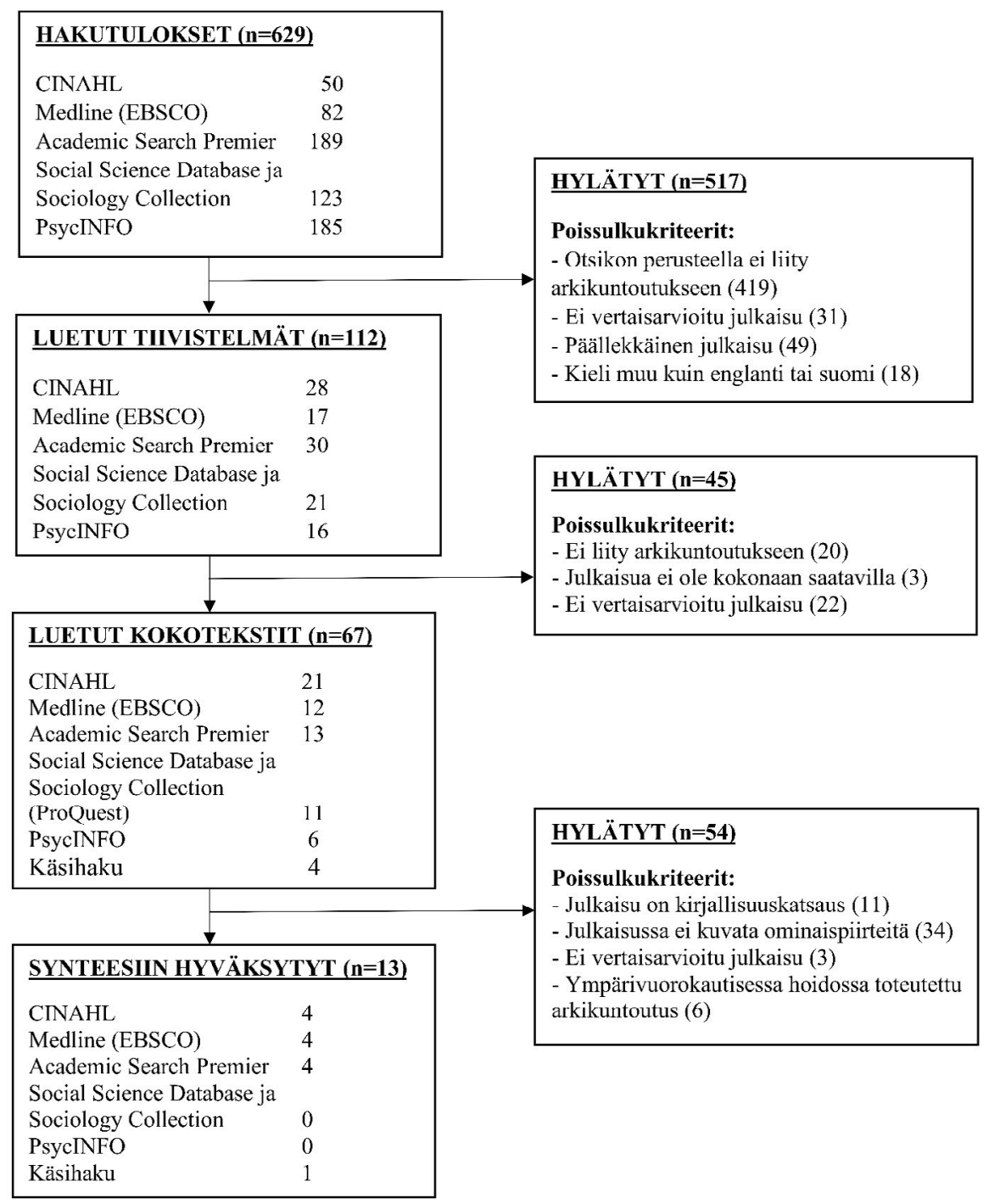

Kuvio 1. Kirjallisuushaun eteneminen.

tutkimustuloksista tekstikatkelmia, joissa kuvattiin arkikuntoutusta. Kuvaukset pilkottiin yksittäisiin sanoihin, sanapareihin tai virkkeisiin. Samalla huomioitiin, että tekstiä ei irrotettu asiayhteydestä. Synteesistä jätettiin pois ne tekstikohdat, joissa mainittiin arkikuntoutusta toteuttavan organisaation nimi, tutkimusta varten käytettyjen mittareiden nimet, kuvauk- set siitä, miten arkikuntoutus eroaa tutkimusasetelman kontrolliryhmästä, kuvaukset arkikuntoutuksen koulutuksesta henkilöstölle sekä kuvaukset asiakkaan kokemuksista arkikuntoutuksesta. Aineistoa muodostui yhteensä 410 sanaa, sanaparia tai virkettä, ja yhdestä artikkelista muodostui enintään 75 ja vähintään 5 sanaa, sanaparia tai virkettä. 
Taulukko 1. Kirjallisuuskatsaukseen valitut julkaisut.

\begin{tabular}{|c|c|c|c|c|}
\hline Nro & $\begin{array}{l}\text { Tekijät, vuosi, } \\
\text { maa }\end{array}$ & Tutkimuksen tarkoitus & Aineisto ja tutkimusmenetelmät & $\begin{array}{l}\text { Katsauksen kannalta keskeiset } \\
\text { tulokset }\end{array}$ \\
\hline 1. & $\begin{array}{l}\text { Lewin ym. } \\
2013 a \\
\text { Australia }\end{array}$ & $\begin{array}{l}\text { Arvioida } \\
\text { arkikuntoutuksen } \\
\text { pitkän aikavälin } \\
\text { kustannus-vaikuttavuutta. }\end{array}$ & $\begin{array}{l}\text { Rekisteriaineisto retrospektiivisen } \\
\text { tutkimuksen avulla } 57 \text { kuukauden } \\
\text { ajalta. } \mathrm{N}=10368 \text { henkilöä, joista } \\
\text { oli } 2586 \text { arkikuntoutuksen (HIP*), } \\
5450 \text { sairaalasta kotiutuvien arki- } \\
\text { kuntoutuksen (PEP**) ja } 2332 \\
\text { tavanomaisen kotihoidon } \\
(\text { HACC } * * *) \text { asiakkaita. }\end{array}$ & $\begin{array}{l}\text { Arkikuntoutus oli tavoitekeskeinen } \\
\text { kuntoutusmuoto, jonka tavoitteet } \\
\text { liittyivät asiakkaan toimintakyvyn ja } \\
\text { itsenäisen suoriutumisen tukemiseen, } \\
\text { asiakkaan terveyttä edistävien ja } \\
\text { sairauksia ehkäisevien taitojen } \\
\text { kehittymiseen sekä asiakkaan } \\
\text { osallisuuden ja aktiivisuuden } \\
\text { tukemiseen. }\end{array}$ \\
\hline 2. & $\begin{array}{l}\text { Lewin \& } \\
\text { Vandermeulen } \\
2010 \\
\text { Australia }\end{array}$ & $\begin{array}{l}\text { Arvioida } \\
\text { arkikuntoutuksen } \\
\text { vaikuttavuutta } \\
\text { ikääntyneiden } \\
\text { kotihoidossa. }\end{array}$ & $\begin{array}{l}\text { Satunnaistamaton kontrolloitu } \\
\text { vertailuasetelma, } N=200 \text {. Verrattiin } \\
\text { arkikuntoutusta }(H I P, n=100) \text { ja } \\
\text { tavanomaista kotihoitoa (HACC, } \\
n=100 \text { ) lähtötilanteessa sekä } \\
3 \text { kuukauden ja } 1 \text { vuoden kuluttua. }\end{array}$ & $\begin{array}{l}\text { Arkikuntoutuksessa laadittiin yksilöl- } \\
\text { linen ja tavoitekeskeinen suunnitel- } \\
\text { ma yhteistyössä asiakkaan kanssa. } \\
\text { Autonomian tunnetta tuettiin, } \\
\text { toteutettiin toiminnan muokkaamista, } \\
\text { toiminnan toteuttamisen uudelleen } \\
\text { suunnittelua ja toiminnan yksinkertais- } \\
\text { tamista sekä fyysisiä harjoitteita. }\end{array}$ \\
\hline 3. & $\begin{array}{l}\text { Lewin ym. } \\
2013 \mathrm{~b} \\
\text { Australia }\end{array}$ & $\begin{array}{l}\text { Arvioida } \\
\text { ikääntyneiden } \\
\text { arkikuntoutuksen } \\
\text { vaikuttavuutta. }\end{array}$ & $\begin{array}{l}\text { Satunnaistettu kontrolloitu koe. } \\
\mathrm{N}=750 \text { osallistujaa, jotka jaettu } \\
\text { arkikuntoutuksen ja tavanomaisen } \\
\text { kotihoidon ryhmiin. Seuranta } \\
\text { toteutettu lähtötilanteessa, } \\
3 \text { kuukauden ja } 12 \text { kuukauden } \\
\text { kuluttua. }\end{array}$ & $\begin{array}{l}\text { Arkikuntoutus oli varhaisessa vaihees- } \\
\text { sa toteutuvaa, kesti niin kauan, että } \\
\text { asiakas saavutti tavoitteet mutta kui- } \\
\text { tenkin enintään } 12 \text { viikkoa. Toteutettiin } \\
\text { toiminnan muokkaamista, toiminnan } \\
\text { toteuttamisen uudelleen suunnittelua } \\
\text { ja toiminnan yksinkertaistamista sekä } \\
\text { fyysisiä harjoitteita. }\end{array}$ \\
\hline 4 . & $\begin{array}{l}\text { Parsons ym. } \\
2013 \\
\text { Uusi-Seelanti }\end{array}$ & $\begin{array}{l}\text { Arvioida } \\
\text { arkikuntoutuksen } \\
\text { vaikuttavuutta } \\
\text { fyysiseen toimintakykyyn } \\
\text { ja sosiaaliseen tukeen } \\
\text { ikääntyneillä. }\end{array}$ & $\begin{array}{l}\text { Satunnaistettu kontrolloitu koe. } \\
N=205 \text {, arkikuntoutus } n=108 \mathrm{ja} \\
\text { tavanomainen hoito } n=97 .\end{array}$ & $\begin{array}{l}\text { Kotihoidon koordinaattori toteutti ar- } \\
\text { vioinnin TARGET-arviointimenetelmää } \\
\text { hyödyntämällä. Tukisuunnitelman to- } \\
\text { teuttamisessa voivat olla mukana myös } \\
\text { muut terveydenhuollon ammattilaiset, } \\
\text { kuten toimintaterapeutti, fysioterapeut- } \\
\text { ti, puheterapeutti, ravitsemusterapeutti. }\end{array}$ \\
\hline 5. & $\begin{array}{l}\text { Whitehead ym. } \\
2016 \\
\text { Iso-Britannia }\end{array}$ & $\begin{array}{l}\text { Arvioida } \\
\text { toimintaterapeutin } \\
\text { osaamisen vaikutuksia } \\
\text { arkikuntoutuksen } \\
\text { vaikuttavuuteen } \\
\text { asiakkaan päivittäisistä } \\
\text { toimista suoriutumisessa. }\end{array}$ & $\begin{array}{l}\text { Satunnaistettu kontrolloitu koe, } \\
\mathrm{N}=30 \text {. Kontrolliryhmällä oli koti- } \\
\text { hoidon arkikuntoutusta sosiaali- } \\
\text { huollon toteuttamana, } \mathrm{n}=15 . \\
\text { Interventioryhmä sisälsi lisäksi } \\
\text { toimintaterapiaa, } \mathrm{n}=15 \text {. }\end{array}$ & $\begin{array}{l}\text { TARGET-arviointimenetelmä sisälsi toi- } \\
\text { mintojen harjoittelua tai uudelleen opet- } \\
\text { telua, päivittäisten toimien itsenäisen } \\
\text { tekemisen vahvistamista, apuvälineiden } \\
\text { kokeilemista ja ympäristön tai toimin- } \\
\text { nan muokkaamista. Toiminnan mahdol- } \\
\text { listamisessa hyödynnettiin toiminnan } \\
\text { analysoimista. Toimintaterapeutti } \\
\text { myönsi tarvittavat apuvälineet ja } \\
\text { muutostyöt asiakkaalle. }\end{array}$ \\
\hline 6. & $\begin{array}{l}\text { Tuntland ym. } \\
2014 \\
\text { Norja }\end{array}$ & $\begin{array}{l}\text { Tutkimusprotokolla } \\
\text { arkikuntoutuksen } \\
\text { vaikuttavuuden ja } \\
\text { kustannus- } \\
\text { vaikuttavuuden } \\
\text { tutkimisesta. }\end{array}$ & $\begin{array}{l}\text { Satunnaistettu koeasetelma, } \\
\text { vertaillaan arkikuntoutusta (inter- } \\
\text { ventio) ja tavanomaista kotihoitoa } \\
\text { (kontrolli), } \mathrm{N}=60 \text {. Aineiston keruu } \\
\text { toteutui lähtötilanteessa, } 3 \text { ja } \\
9 \text { kuukauden kuluttua kummassa- } \\
\text { kin ryhmässä ja lisäksi } 15 \text { kuukau- } \\
\text { den kuluttua interventioryhmässä. }\end{array}$ & $\begin{array}{l}\text { Arvioinnissa hyödynnettiin COPM- } \\
\text { arviointimenetelmää toiminta- ja fysio- } \\
\text { terapeutin toteuttamana. COPM:n } \\
\text { avulla tunnistettiin asiakkaan toimin- } \\
\text { nollisuuden rajoitteet, joissa asiakas } \\
\text { haluaa kehittyä. Toimintakykyä tuettiin } \\
\text { ja toimintaa mahdollistettiin sekä } \\
\text { toteutettiin päivittäisiin toimiin liittyviä } \\
\text { harjoitteita. }\end{array}$ \\
\hline 7. & $\begin{array}{l}\text { Langeland ym. } \\
2015 \\
\text { Norja }\end{array}$ & $\begin{array}{l}\text { Tutkimusprotokolla arki- } \\
\text { kuntoutuksen vaikutta- } \\
\text { vuuden ja kustannus- } \\
\text { vaikuttavuuden } \\
\text { tutkimisesta. }\end{array}$ & $\begin{array}{l}\text { Kontrolloitu monikeskustutkimus, } \\
\mathrm{N}=750 \text {. Seurannan toteutus lähtö- } \\
\text { tilanteessa, } 10 \text { viikon, } 6 \text { kuukauden } \\
\text { ja } 12 \text { kuukauden kuluttua. }\end{array}$ & $\begin{array}{l}\text { Arvioinnissa hyödynnettiin COPM- } \\
\text { arviointimenetelmää toiminta- ja fysio- } \\
\text { terapeutin, hoitajan sekä "sosiaalikou- } \\
\text { luttajan" toteuttamana. Tavoitteena oli } \\
\text { tukea asiakasta omien aktiivisuustavoit- } \\
\text { teiden saavuttamisessa, ja arkikuntou- } \\
\text { tuksessa tuettiin voimaantumista sekä } \\
\text { itsenäistä harjoittelua. }\end{array}$ \\
\hline
\end{tabular}




\begin{tabular}{|c|c|c|c|c|}
\hline Nro & $\begin{array}{l}\text { Tekijät, vuosi, } \\
\text { maa }\end{array}$ & Tutkimuksen tarkoitus & Aineisto ja tutkimusmenetelmät & $\begin{array}{l}\text { Katsauksen kannalta keskeiset } \\
\text { tulokset }\end{array}$ \\
\hline 8. & $\begin{array}{l}\text { King ym. } 2012 \\
\text { Uusi-Seelanti }\end{array}$ & $\begin{array}{l}\text { Arvioida } \\
\text { arkikuntoutuksen } \\
\text { vaikutuksia kotihoidossa } \\
\text { oleville asiakkaille. }\end{array}$ & $\begin{array}{l}\text { Ryvässatunnaistettu otanta ja } \\
\text { arkikuntoutuksen vertailu tavan- } \\
\text { omaiseen kotihoitoon, } \mathrm{N}=186 . \\
\text { Ikääntyneitä haastateltiin lähtö- } \\
\text { tilanteessa, neljän ja seitsemän } \\
\text { kuukauden kuluttua. }\end{array}$ & $\begin{array}{l}\text { Hoitajan kontaktien määrä asiakkaa- } \\
\text { seen vaihteli päivittäisestä kontaktista } \\
\text { joka toinen viikko toteutuvaan kon- } \\
\text { taktiin vähintään kahden viikon ajan. } \\
\text { Arkikuntoutus suunnattiin } 65 \text { vuotta } \\
\text { täyttäneille. }\end{array}$ \\
\hline 9. & $\begin{array}{l}\text { Hjelle ym. } 2017 \\
\text { Norja }\end{array}$ & $\begin{array}{l}\text { Kuvata ikääntyneiden } \\
\text { kokemuksia } \\
\text { arkikuntoutuksesta. }\end{array}$ & $\begin{array}{l}\text { Puolistrukturoitu haastattelu, } \mathrm{N}=8 . \\
\text { Neljä asiakasta haastateltiin kuu- } \\
\text { kausi ennen arkikuntoutusjaksoa ja } \\
\text { arkikuntoutusjakson jälkeen. Neljä } \\
\text { asiakasta haastateltiin vain arki- } \\
\text { kuntoutusjakson jälkeen. }\end{array}$ & $\begin{array}{l}\text { Arkikuntoutuksessa laadittiin yksilölli- } \\
\text { nen ja tavoitekeskeinen suunnitelma. } \\
\text { Arkikuntoutustiimi tuki asiakasta otta- } \\
\text { maan vastuuta omasta aktiivisuudes- } \\
\text { taan arkikuntoutuksessa. Työntekijät } \\
\text { sopeuttivat arkikuntoutuksessa anta- } \\
\text { mansa tuen ikääntyneille siten, että } \\
\text { asiakas koki varmuutta ja turvallisuutta. } \\
\text { Asiakkaan oma tahdonvoima ja päättä- } \\
\text { väisyys olivat keskeisiä arkikuntoutuk- } \\
\text { sen toteutumisessa. }\end{array}$ \\
\hline 10. & $\begin{array}{l}\text { Tinetti ym. } 2012 \\
\text { Connecticut, } \\
\text { USA }\end{array}$ & $\begin{array}{l}\text { Arvioida arkikuntoutuksen } \\
\text { vaikuttavuutta } \\
\text { sairaalajakson jälkeen } \\
\text { verrattuna tavanomaiseen } \\
\text { kotihoitoon. }\end{array}$ & $\begin{array}{l}\text { Kaltaistettujen parien menetelmä. } \\
\mathrm{N}=770 \text {, joista muodostettiin } \\
341 \text { kaltaistettua paria. }\end{array}$ & $\begin{array}{l}\text { Arkikuntoutuksessa laadittiin yksilöl- } \\
\text { linen ja tavoitekeskeinen suunnitel- } \\
\text { ma yhteistyössä asiakkaan, perheen, } \\
\text { kotihoidon henkilökunnan ja hoitajien } \\
\text { kanssa. Suunnitelma sisälsi harjoittei- } \\
\text { ta, asiakkaan toimintatavan muutoksia, } \\
\text { itsensä johtamista, ympäristön tai apu- } \\
\text { välineiden muokkaamista, asiakkaiden, } \\
\text { perheen sekä hoitajien harjoittelua ja } \\
\text { neuvontaa sekä lääkemuutoksia. Lisäksi } \\
\text { suunnitelman tavoitteet liittyivät fyy- } \\
\text { sisiin häiriöihin ja päivittäisiin toimiin. } \\
\text { Arkikuntoutus sisälsi jatkuvaa seurantaa } \\
\text { ja selkeät roolijaot. }\end{array}$ \\
\hline 11. & $\begin{array}{l}\text { Mann ym. } 2016 \\
\text { Iso-Britannia }\end{array}$ & $\begin{array}{l}\text { Tutkimusprotokolla, jossa } \\
\text { arvioidaan erilaisten arki- } \\
\text { kuntoutusmenetelmien } \\
\text { vaikuttavuutta ja kustan- } \\
\text { nusvaikuuttavuutta sekä } \\
\text { asiakkaiden ja henkilö- } \\
\text { kunnan kokemuksia. }\end{array}$ & $\begin{array}{l}\text { Tutkimusprotokolla arkikuntou- } \\
\text { tuksen vaikutusten arvioinnista } \\
\text { kvasikokeellisella asetelmalla ja } \\
\text { monimenetelmäisellä tutkimus- } \\
\text { otteella, } \mathrm{N}=800 \text {. }\end{array}$ & $\begin{array}{l}\text { Arkikuntoutuksen tavoitteena oli asi- } \\
\text { akkaan itsenäisen toimintakyvyn tu- } \\
\text { keminen ja arkikuntoutus suunnattiin } \\
\text { täysi-ikäisille. }\end{array}$ \\
\hline 12. & $\begin{array}{l}\text { Rabiee \& } \\
\text { Glendinning, } \\
2011 \\
\text { Iso-Britannia }\end{array}$ & $\begin{array}{l}\text { Arvioida arkikuntoutuksen } \\
\text { organisointia ja toteutusta } \\
\text { kotihoidossa. }\end{array}$ & $\begin{array}{l}\text { Laadullinen tutkimus, } \mathrm{N}=71 . \\
\text { Puolistrukturoitu haastattelu } \\
\mathrm{n}=8 \text {, arkikuntoutuskäyntien } \\
\text { havainnointi } \mathrm{n}=26 \text { ja ryhmä- } \\
\text { muotoinen henkilöstön teema- } \\
\text { haastattelu } \mathrm{n}=37 \text { työntekijää. }\end{array}$ & $\begin{array}{l}\text { Arkikuntoutus edellytti johdonmukaista } \\
\text { ja perusteellista kirjaamista, jossa kuvat- } \\
\text { tiin, miten arkikuntoutuksessa edetään } \\
\text { kohti tavoitetta. Arkikuntoutuksen valin- } \\
\text { takriteerit eivät olleet tarkkoja eivätkä } \\
\text { samat kaikilla työntekijöillä. Asiakkaan } \\
\text { toimintakyvyn kohenemisen arvioitu } \\
\text { nopeus vaikutti keskeisesti arkikuntou- } \\
\text { tukseen pääsemiseen. }\end{array}$ \\
\hline 13. & $\begin{array}{l}\text { Whitehead ym. } \\
2014 \\
\text { Iso-Britannia }\end{array}$ & $\begin{array}{l}\text { Tutkimusprotokolla, } \\
\text { tavoitteena arvioida } \\
\text { toimintaterapeutin } \\
\text { osaamisen vaikutuksia } \\
\text { arkikuntoutuksen } \\
\text { vaikuttavuudelle. }\end{array}$ & $\begin{array}{l}\text { Satunnaistettu kontrolloitu koe, } \\
\mathrm{N}=50 \text {. Kotihoidon toteuttama arki- } \\
\text { kuntoutus ilman toimintaterapiaa } \\
\text { ja toimintaterapian kanssa. }\end{array}$ & $\begin{array}{l}\text { Asiakkaan toimintakyvyn ja itsenäi- } \\
\text { sen suoriutumisen tukemiseen liittyviä } \\
\text { tavoitteita olivat: asiakkaan aktiivisuu- } \\
\text { den ja riippumattomuuden edistäminen } \\
\text { päivittäisissä toimissa, kuten peseyty- } \\
\text { misessä, pukeutumisessa ja ruokailussa. } \\
\text { Neuvoja ja tietoa annettiin myös per- } \\
\text { heenjäsenille tai avustajille. }\end{array}$ \\
\hline
\end{tabular}

*the Home Independence Program, **the Personal Enablement Program, ***the Home and Community Care 
Tulosten lajittelu ja yhteenveto

Aineiston sanat, sanaparit ja virkkeet ryhmiteltiin sisällön mukaan seitsemään alustavaan ryhmään: Arkikuntoutuksen 1) kuvaus, 2) tavoitteet, 3) käytännössä toteutettavat toiminnot ja harjoitteet, 4) käytettävät menetelmät ja mittarit, 5) kesto, 6) toteutukseen osallistuvat ammattilaiset ja henkilöt ja 7) kohderyhmä. Ryhmät muodostettiin aineistolähtöisesti sen perusteella, mitä teemoja aineistossa käsiteltiin. Tämän jälkeen aineisto edelleen ryhmiteltiin sisällön perusteella 14 alaluokkaan (ks. kuvio 2). Alaluokkaryhmittely toteutettiin käytännössä siten, että jokaista väliryhmää tarkasteltiin vuorotellen lukemalla aineisto läpi. Tekstit koodattiin värikoodauksella sisällön mukaan ja samansisältöiset tekstikappaleet yhdistettiin alaluokiksi. Tekstit, joille ei löytynyt samansisältöistä paria kyseisestä väliryhmästä, sijoitettiin toiseen alaluokkaan tai niille muodostettiin oma alaluokka.
Alaluokat ryhmiteltiin sisällön samankaltaisuuden perusteella neljään yläluokkaan. Yläja alaluokat kuvasivat arkikuntoutuksen ominaispiirteitä. Synteesiin otettiin mukaan kaikki kuvaukset arkikuntoutuksen ominaispiirteistä riippumatta siitä, kuinka monessa julkaisussa kyseinen ominaispiirre ilmeni. Aineiston luokittelu ala- ja yläluokkiin on esitetty kuviossa 2 .

\section{Tulokset}

Kirjallisuuskatsaukseen valikoituneet artikkelit $(\mathrm{N}=13)$ olivat märällisiä $(\mathrm{n}=11)$ ja laadullisia $(n=2)$ tutkimuksia, satunnaistettuja $(n=6)$ ja satunnaistamattomia $(n=8)$ tutkimuksia sekä tutkimusprotokollia $(\mathrm{n}=4)$. Arkikuntoutuksen ominaispiirteet on esitetty kuviossa 2 . Tekstiin on kirjattu sulkuihin artikkelin numero, jossa ominaispiirre on esitetty. Artikkelit numeroineen sekä lisätietoineen on esitelty taulukossa 1.

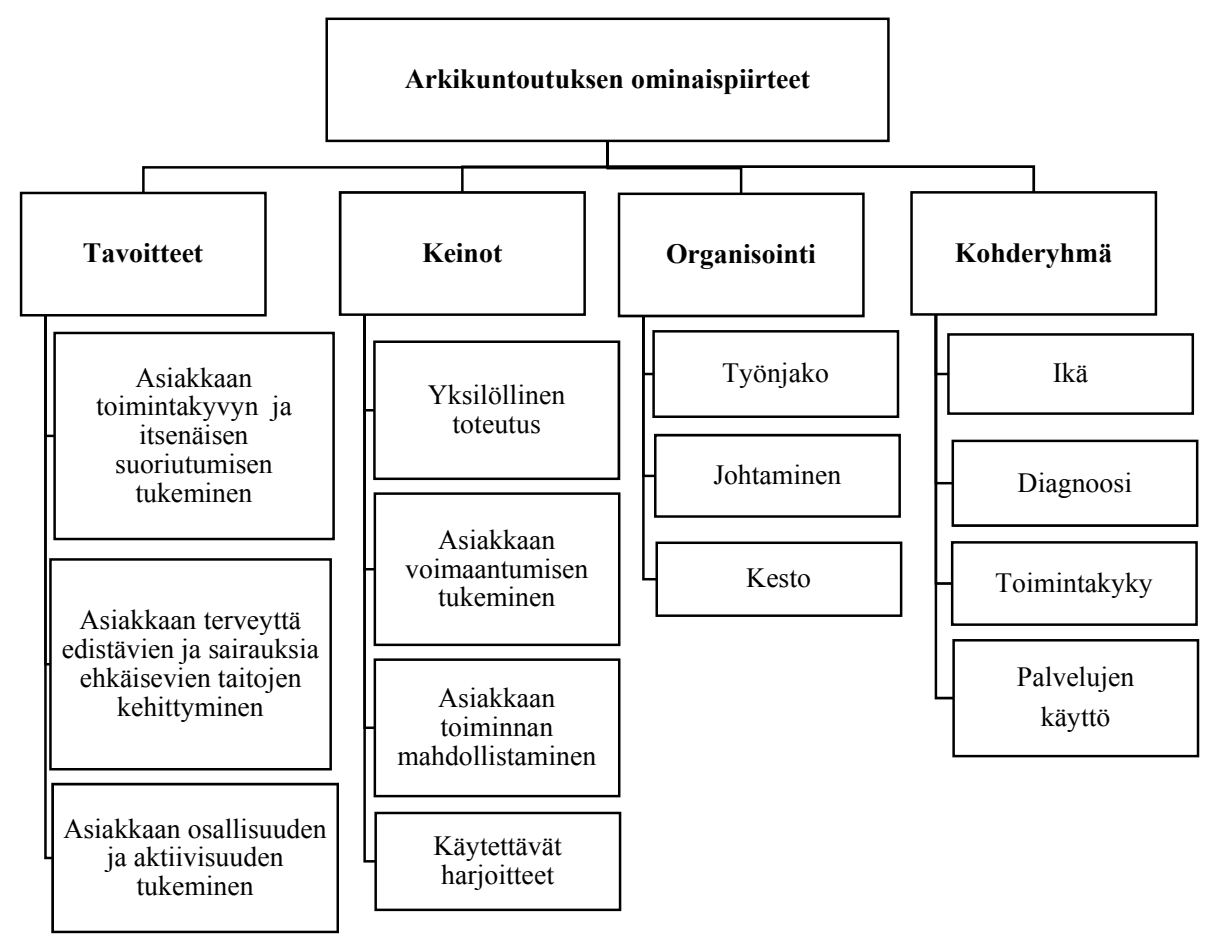

Kuvio 2. Arkikuntoutuksen ominaispiirteet. 


\section{Arkikuntoutuksen tavoitteet}

Arkikuntoutusta kuvattiin tavoitekeskeiseksi kuntoutuksen muodoksi (Rabiee \& Glendinning 2011; Lewin ym. 2013a; Hjelle ym. 2017). Arkikuntoutuksen tavoitteet liittyivät asiakkaan toimintakyvyn ja itsenäisen suoriutumisen tukemiseen, asiakkaan terveyttä edistävien ja sairauksia ehkäisevien taitojen kehittymiseen sekä asiakkaan osallisuuden ja aktiivisuuden tukemiseen.

Asiakkaan toimintakyvyn ja itsenäisen suoriutumisen tukeminen oli keskeinen tavoite arkikuntoutuksessa (Lewin \& Vandermeulen 2010; Tinetti ym. 2012; Lewin ym. 2013a; Lewin ym. 2013b; Tuntland ym. 2014; Whitehead ym. 2014; Langeland ym. 2015; Mann ym. 2016; Whitehead ym. 2016; Hjelle ym. 2017). Tavoitteina olivat muun muassa: asiakkaan aktiivisuuden ja riippumattomuuden edistäminen päivittäisissä toimissa, kuten peseytymisessä, pukeutumisessa ja ruokailussa (Whitehead ym. 2014; Whitehead ym. 2016), asiakkaiden rohkaiseminen ja tukeminen arjen toteuttamisessa (Hjelle ym. 2017) ja asiakkaan tukipalvelutarpeen minimointi (Lewin ym. 2013a; Lewin ym. 2013b).

Asiakkaan terveyttä edistävien ja sairauksia ehkäisevien taitojen kehittymiseen liittyviä tavoitteita olivat sairauksien ja ihon omahoidon tukeminen, kaatumisen ehkäiseminen sekä lääkkeisiin ja ravitsemukseen liittyvän itsehoidon tukeminen (Lewin \& Vandermeulen 2010; Lewin ym. 2013a; Lewin ym. 2013b). Henkilökunnan työote muuttui sairauksien hoitamisesta asiakkaan toteuttaman omahoidon tukemiseen (Tinetti ym. 2012). Tavoitteena oli myös ehkäistä asiakkaan sairaalaan joutumista (Lewin ym. 2013a).

Asiakkaan osallisuuden ja aktiivisuuden tukemiseen liittyviä tavoitteita olivat niiden toimintamallien parantaminen ja ylläpitäminen, joiden avulla yksittäinen henkilö voi olla yhteydessä yhteiskuntaan ja jotka auttavat yksilöä sosiaalisen aktiivisuuden palauttamiseen (Lewin ym. 2013a). Lisäksi tavoitteena oli tukea asia- kasta omien aktiivisuustavoitteiden saavuttamisessa (Langeland ym. 2015).

\section{Arkikuntoutuksen keinot}

Arkikuntoutuksen keinoina käytettiin yksilöllistä toteutusta, asiakkaan voimaantumisen tukemista, asiakkaan toiminnan mahdollistamista sekä arkikuntoutuksessa käytettäviä harjoitteita.

Yksilöllinen toteutus oli keskeistä arkikuntoutuksessa (Tinetti ym. 2012; Lewin ym. 2013a; Tuntland ym. 2014; Langeland ym. 2015; Hjelle ym. 2017). Asiakkaan ja työntekijän välisessä vuoropuhelussa yksilöitiin asiakkaalle mielekkäitä toimintoja, joiden toteuttamisessa asiakkaalla on haasteita (Langeland ym. 2015; Hjelle ym. 2017). Esimerkiksi asiakkaalle saattoi olla tärkeämpää suoriutua ulkotöistä kuin kodinhoidosta (Hjelle ym. 2017).

Arkikuntoutuksen yksilöllisten tavoitteiden laatimisessa hyödynnettiin kattavaa arviointia (Rabiee \& Glendinning 2011; Tinetti ym. 2012; Whitehead ym. 2014). Arvioinnissa hyödynnettiin COPM- (Canadian Occupational Performance Measure) (Tuntland ym. 2014; Langeland ym. 2015) tai TARGET- (Towards Achieving Realistic Goals in Elders Tool) (Parsons ym. 2013; Whitehead ym. 2016) arviointimenetelmiä. COPM-haastattelun avulla tunnistettiin asiakkaan toiminnollisuuden rajoitteet, joissa asiakas haluaa kehittyä (Tuntland ym. 2014; Langeland ym. 2015). COPM:sta saatua tietoa käytettiin kuntoutussuunnitelman laatimiseen (Tuntland ym. 2014; Langeland ym. 2015) sekä asiakkaan tarpeiden, hoidon painopisteiden ja interventioiden välisen yhteensopivuuden varmistamiseen (Tuntland ym. 2014). COPM-haastattelu ja pisteytys alkavat kysymyksellä: "Mitkä ovat tärkeimmät toiminnot elämässäsi nyt?” (Langeland ym. 2015). TARGET-arviointimenetelmä sisälsi toimintojen harjoittelua tai uudelleen opettelua, päivittäisten toimien itsenäisen tekemisen vahvistamista, apuvälineiden kokeilemista ja ympäristön tai toiminnan muokkaamista 
(Whitehead ym. 2016). Yksilölliseen arviointiin sisältyi myös kaatumisen riskin, lihasvoiman heikentymisen, peseytymisvaikeuksien ja muiden henkilökohtaisten huolenaiheiden arviointi, jotka ehkä estävät ikääntynyttä saavuttamaan tavoitteensa (Parsons ym. 2013).

Arkikuntoutuksessa laadittiin yksilöllinen ja tavoitekeskeinen suunnitelma (Lewin \& Vandermeulen 2010; Tinetti ym. 2012; Parsons ym. 2013; Langeland ym. 2015; Hjelle ym. 2017). Suunnitelman laatimiseen osallistuivat asiakas (Lewin \& Vandermeulen 2010; Tinetti ym. 2012; Parsons ym. 2013; Langeland ym. 2015; Hjelle ym. 2017), perhe (Tinetti ym. 2012), toiminta- tai fysioterapeutti (Tuntland ym. 2014), kotihoidon henkilökunta (Tinetti ym. 2012; Parsons ym. 2013) ja/tai hoitajat (Tinetti ym. 2012). Suunnitelma sisälsi harjoitteita, asiakkaan toimintatavan muutoksia, itsensä johtamista, ympäristön tai apuvälineiden muokkaamista, asiakkaiden, perheen sekä hoitajien harjoittelua ja neuvontaa sekä lääkemuutoksia (Tinetti ym. 2012; Whitehead ym. 2014). Lisäksi suunnitelman tavoitteet liittyivät fyysisiin häiriöihin ja päivittäisiin toimiin (Tinetti ym. 2012). Neuvoja ja tietoa annettiin myös perheenjäsenille tai avustajille (Whitehead ym. 2014). TARGET-arviointia hyödyntäneessä arkikuntoutuksessa suunniteltiin yhdessä pitkän aikavälin tavoitteet sekä tarvittavat lyhyen aikavälin tavoitteet tavoiteportaiden avulla. Lisäksi laadittiin konkreettinen tukisuunnitelma kotihoidon apuvälineeksi. Tukisuunnitelma sisälsi yksityiskohtaisen kuvauksen suoritettavista tehtävistä. (Parsons ym. 2013.) Itsehoitosuunnitelmassa kuvattiin päivittäiset toimet jakamalla ne, mikä auttoi selventämään tavoitteita, osoitti lähtötason, yhdenmukaisti arvioinnin, selvensi palveluntarjoajien hoitovastuuta ja prosessin edistymisen seuraamista (Tinetti ym. 2012). Muita suunnitelmista käytettyjä käsitteitä olivat kuntoutussuunnitelma ja hoitosuunnitelma (Lewin \& Vandermeulen 2010; Parsons ym. 2013).

Arkikuntoutuksen yksilöllisyys ilmeni myös siten, että jatkuvaa seurantaa pidettiin keskei- senä arkikuntoutuksen onnistumisessa (Rabiee \& Glendinning 2011; Tinetti ym. 2012). Arkikuntoutus edellytti johdonmukaista ja perusteellista kirjaamista, jossa kuvattiin, miten arkikuntoutuksessa edetään kohti tavoitetta. Asiakaskäynnistä tuli kirjata, mitä tehdään, kuinka pitkälle asiakas on edistynyt tavoitteiden saavuttamisessa ja millaisia riskitekijöitä on ilmennyt. Esimerkiksi tyypillinen puute kirjaamisessa oli, että kirjauksessa oli todettu, mitä oli tehty (kuten "avustettu mekko", "tehtiin voileipä", "sijattu sänky"), mutta ei kerrottu, miten se toteutettiin, miten asiakas oli mukana näissä tehtävissä ja miten avustamisen ja tuen määrä muuttui arkikuntoutusjakson aikana. (Rabiee \& Glendinning 2011.)

Asiakkaan voimaantumista tuettiin kannustamalla asiakasta tekemään itse (Rabiee \& Glendinning 2011; Tinetti ym. 2012; Langeland ym. 2015; Hjelle ym. 2017). Asiakasta kannustettiin tekemään päivittäisiä toimia ja päivittäisiä harjoitteita sen sijaan, että asiakkaat saisivat apua tai antaisivat muiden tehdä toimet itselleen (Tuntland ym. 2014; Langeland ym. 2015; Hjelle ym. 2017). Käytännössä tämä toteutettiin siten, että ajoittain henkilökunta vain seurasi asiakkaan toimia (Rabiee \& Glendinning 2011; Hjelle ym. 2017). Lisäksi asiakasta tuettiin itsensä johtamiseen (Lewin \& Vandermeulen 2010; Tuntland ym. 2014; Langeland ym. 2015; Hjelle ym. 2017) ja itsenäiseen harjoitteluun (Lewin \& Vandermeulen 2010; Tuntland ym. 2014; Langeland ym. 2015; Hjelle ym. 2017). Arkikuntoutuksessa hyödynnettiin puhetyyliä ja menetelmiä, jotka rohkaisevat asiakasta ja perhettä osallistumaan kaikkeen hoidon päätöksentekoon, joka tukee heidän autonomian tunnettaan, ja vältettiin asiakkaan ohittavaa vallan käyttöä tai kontrollointia (Lewin \& Vandermeulen 2010). Arkikuntoutustiimi tuki asiakasta ottamaan vastuuta omasta aktiivisuudestaan arkikuntoutuksessa. Työntekijät sopeuttivat arkikuntoutuksessa antamansa tuen ikääntyneille siten, että asiakas koki varmuutta ja turvallisuutta. Asiakkaan oma tahdonvoima ja päättäväisyys 
olivat keskeisiä arkikuntoutuksen toteutumisessa. (Hjelle ym. 2017.)

Asiakkaan toimintaa mabdollistettiin toiminnan muokkaamisella (Lewin \& Vandermeulen 2010; Lewin ym. 2013a; Lewin ym. 2013b; Tuntland ym. 2014; Langeland ym. 2015). Muokkaamisessa hyödynnettiin toiminnan toteuttamisen uudelleen suunnittelua (Lewin \& Vandermeulen 2010; Lewin ym. 2013a; Lewin ym. 2013b; Tuntland ym. 2014; Langeland ym. 2015) sekä toiminnan yksinkertaistamista (Lewin \& Vandermeulen 2010; Lewin ym. 2013a; Lewin ym. 2013b; Tuntland ym. 2014). Esimerkiksi puuron keittämisen helpottamiseksi henkilökunta saattoi kokeilla asiakkaan kanssa pikahiutaleilla toteutettavan mikropuuron tekemistä tai vaikka vain nostaa kattilan, hiutaleet ja vesikannun asiakkaan käden ulottuville. Lisäksi hyödynnettiin ympäristön muokkaamista (Tinetti ym. 2012; Tuntland ym. 2014; Langeland ym. 2015; Whitehead ym. 2016), joka toteutettiin esimerkiksi puoliaskelmien tai kynnysten poistamisella tai vaihtamisella tai porraskiipijän hankinnalla (Whitehead ym. 2016). Apuvälineet tai pienet muutostyöt olivatkin keskeisessä roolissa arkikuntoutusjakson aikana (Whitehead ym. 2014; Whitehead ym. 2016). Apuvälineiden avulla (Lewin \& Vandermeulen 2010; Tinetti ym. 2012; Lewin ym. 2013a; Lewin ym. 2013b; Tuntland ym. 2014) toimintaa mahdollistettiin esimerkiksi neuvomalla sopivan apuvälineen käytössä (Tuntland ym. 2014) ja mukauttamalla apuvälinettä (Tinetti ym. 2012). Toiminnan mahdollistamisessa hyödynnettiin myös toiminnan analysoimista (Lewin \& Vandermeulen 2010; Lewin ym. 2013a; Lewin ym. 2013b; Whitehead ym. 2016), jossa toiminta jaoteltiin osiin ja tunnistettiin ne toiminnan elementit, joita asiakas ei pystynyt suorittamaan (Whitehead ym. 2016).

Arkikuntoutuksessa käytettiin kolmen tyyppisiä harjoitteita. Fyysiseen toimintakykyyn keskittyviä harjoitteita (Lewin \& Vandermeulen 2010; Lewin ym. 2013a; Lewin ym. 2013b; Tuntland ym. 2014; Langeland ym. 2015;
Hjelle ym. 2017) olivat muun muassa voima- ja tasapainoharjoitteet (Lewin \& Vandermeulen 2010; Lewin ym. 2013a; Lewin ym. 2013b; Tuntland ym. 2014; Langeland ym. 2015) sekä kestävyys- (Lewin \& Vandermeulen 2010; Lewin ym. 2013a; Lewin ym. 2013b) ja siirtymisharjoitteet (Tuntland ym. 2014). Lisäksi harjoiteltiin sisällä ja ulkona kävelemistä (Tuntland ym. 2014; Langeland ym. 2015), kävelyä apuvälineen kanssa ja ilman (Tuntland ym. 2014), portaissa kävelyä (Tuntland ym. 2014; Langeland ym. 2015; Hjelle ym. 2017) sekä tehtiin hienomotorisia harjoitteita (Tuntland ym. 2014; Langeland ym. 2015). Harjoitteet sisällytettiin päivittäisiin rutiineihin, ja asiakas sai kirjalliset ohjeet, joissa oli kuvattu kaikki harjoitteet ja joissa rohkaistiin itsenäiseen harjoitteluun (Tuntland ym. 2014; Langeland ym. 2015).

Päivittäisiin toimintoihin keskittyviä harjoitteita (Rabiee \& Glendinning 2011; Tuntland ym. 2014; Langeland ym. 2015; Hjelle ym. 2017) olivat muun muassa pukeutuminen ja ruuan valmistus (Rabiee \& Glendinning 2011; Tuntland ym. 2014), kodin siivoaminen (Tuntland ym. 2014; Langeland ym. 2015; Hjelle ym. 2017), sängyn petaaminen (Rabiee \& Glendinning 2011), henkilökohtainen hygienia (Langeland ym. 2015) ja peseytyminen (Hjelle ym. 2017). Vapaa-ajan toimiin ja sosiaaliseen aktiivisuuteen keskittyviä harjoitteita (Lewin \& Vandermeulen 2010; Tuntland ym. 2014; Langeland ym. 2015; Hjelle ym. 2017) olivat esimerkiksi neulominen ja ystävien luona käyminen (Tuntland ym. 2014), bussilla liikkuminen (Tuntland ym. 2014; Hjelle ym. 2017) sekä perheen luona vierailu ja kirjoittaminen (Langeland ym. 2015). Arkikuntoutuksessa tunnistetaan sosiaalisen tuen merkitys kotihoidossa oleville ikääntyneille ja tunnistetaan, että asiakas tarvitsee kotihoidon sijaan muita keinoja saavuttaakseen sosiaalisen tuen (Lewin \& Vandermeulen 2010). Arkikuntoutuksessa tuettiin esimerkiksi asiakasta matkustamaan bussilla kokeilemalla sitä asiakkaan kanssa yhdessä. Arkikuntoutuksessa tuettiin asiakkaan 
kokemusta, että hänet muistetaan ja häntä rakastetaan. Arkikuntoutuksessa tuettiin sitä, että asiakas voi kyläillä säännöllisesti ja asiakkaalla on mahdollisuudet osallistua vapaa-ajan toimintoihin ja sosiaaliseen elämään. (Hjelle ym. 2017.)

\section{Arkikuntoutuksen organisointi}

Arkikuntoutuksen organisoinnissa ilmeni työnjakoon, johtamiseen ja arkikuntoutuksen kestoon liittyviä ominaispiirteitä. Arkikuntoutuksessa työnjako painottui eri tavoin, mutta keskeisenä tekijänä oli, että sitä toteutettiin moniammatillisesti (Tinetti ym. 2012; Langeland ym. 2015). Toimintaterapeutti ja fysioterapeutti (Tuntland ym. 2014; Langeland ym. 2015), hoitaja tai sosiaalikouluttaja (Langeland ym. 2015) käyttivät COPM-haastattelua osana alkuarviointia tunnistaakseen toiminnallisuuden rajoitteet, jotka ovat asiakkaalle tärkeitä (Tuntland ym. 2014). Toiminta- tai fysioterapeutti laativat kuntoutussuunnitelmaa yhdessä asiakkaan kanssa tunnistettujen toiminnallisten tavoitteiden pohjalta (Tuntland ym. 2014). Toimintaterapeutti toteutti arvioinnin viiden työpäivän kuluessa arkikuntoutuksen alkamisesta. Toimintaterapeutti yksilöi haasteet, joita asiakkaalla voi olla esimerkiksi päivittäisissä toimissa fyysisiin tai psyykkisiin haasteisiin tai näiden yhdistelmään. (Whitehead ym. 2014.)

Alkuarvioinnin saattoivat toteuttaa ikääntyneiden kanssa myös koordinaattoreiksi nimetyt kokeneet ja laillistetut sairaanhoitajat. Koordinaattorit toteuttivat myös seurantakeskusteluja puhelimitse tai kotikäynteinä kolmen kuukauden välein sekä täydellisen uudelleenarvioinnin 12 kuukauden kuluttua ensimmäisestä arvioinnista. (King ym. 2012.) TARGET-arviointimenetelmää käytettäessä kotihoidon koordinaattori laati konkreettisia ohjeita tukisuunnitelman muodossa kotihoidon apuvälineeksi tavoiteportaisiin perustuen. Tukisuunnitelman toteuttamisessa voivat olla mukana myös muut terveydenhuollon ammattilaiset (toimintaterapeutti, fysioterapeutti, pu- heterapeutti, ravitsemusterapeutti) ohjaamassa asiakasta saavuttamaan tavoitteensa. (Parsons ym. 2013.)

Arkikuntoutusta kuvailtiin monitahoiseksi (Rabiee \& Glendinning 2011; King ym. 2012; Hjelle ym. 2017) ja monialaiseksi (Tinetti ym. 2012) palveluksi. Toiminta- ja fysioterapeutti ohjasivat kotihoidon henkilökuntaa, miten rohkaista ja auttaa asiakkaita päivittäisissä harjoitteissa (Tuntland ym. 2014). Integroitu moniammatillinen tiimi, jolla oli yhteiset tavoitteet, ohjasi osallistujaa koko kuntoutusjakson ajan (Tuntland ym. 2014; Langeland ym. 2015). Kotihoidon työntekijät avustivat asiakasta harjoituksissa, vähintään yhden tunnin kerrallaan, ja toiminta- tai/ja fysioterapeutti ohjasivat harjoitteissa viikoittain (Tuntland ym. 2014). Arkikuntoutus sisälsi toistuvia harjoitteita ja monipuolisia kotikäyntejä terveydenhuoltohenkilöstön tukemana. Henkilöstö oli mukana päivittäisessä harjoittelussa rakentamassa asiakkaan luottamusta sekä uudelleenoppimisen taitoja. (Tuntland ym. 2014; Langeland ym. 2015.) Toimintaterapeutti myönsi tarvittavat apuvälineet ja muutostyöt asiakkaalle. Tarvittavat muutostyöt toteutettiin ja apuvälineet asennettiin yleensä viikon kuluessa määräämisestä ja ennen kuin arkikuntoutusjakso oli päättynyt. (Whitehead ym. 2016.) Toimintaterapeutti huolehti arkikuntoutusjakson ajan apuvälineiden huollosta sekä varmisti, että apuvälineet olivat käytössä ja asiakas tarvitsi niitä (Whitehead ym. 2014; Whitehead ym. 2016). Toimintaterapeutti toteutti vähintään viikoittain arviointia, arkikuntoutuksen koordinointia ja muita palveluja (Whitehead ym. 2014).

Kun arkikuntoutustiimiin sisältyi vain hoitajia, arkikuntoutuksesta saatavaan hyötyyn vaikutti merkittävästi se, että asiakas sai nopeasti erityisammattilaisen, kuten toimintaja fysioterapeutin apua. Lisäksi nopea pääsy monien muiden ammattilaisten vastaanotolle koettiin ratkaisevan tärkeäksi. (Rabiee \& Glendinning 2011.) Arkikuntoutuksen toteutus vaihteli myös hoitotyön osalta, ja arkikuntoutusta toteutettiin hoitotyöhön yhdistetty- 
nä palveluna sekä ilman hoitotyön toteutusta (Lewin ym. 2013a). Arkikuntoutusta toteutettiin sekä integroituna että erillisenä palveluna. Esimerkiksi palveluasumisen yksiköissä, joissa arkikuntoutus integroitiin kotihoidon palveluun, hoitajat joutuivat työskentelemään kaksoisroolissa. Hoitajien odotettiin toteuttavan arkikuntoutusta myös pitkäaikaista kotihoitoa saavien asiakkaiden kanssa, mikäli asiakas oli potentiaalinen arkikuntoutusasiakas. (Rabiee \& Glendinning 2011.)

Arkikuntoutuksen johtamista ja koordinointia kuvattiin monin tavoin muun muassa ohjautumisen, resurssien käytön, henkilöstön luovuuden tukemisen sekä henkilöstön koulutuksen näkökulmista. Arkikuntoutukseen ohjauduttiin esimerkiksi Norjassa siten, että kuntien terveyspalveluista vastaava taho tunnisti potentiaaliset arkikuntoutusasiakkaat ja heille ilmoitettiin uudesta palvelusta sekä kutsuttiin osallistumaan palveluun. (Tuntland ym. 2014; Hjelle ym. 2017.) Arkikuntoutuksen onnistumisen kannalta oli keskeistä, että kaikilla sidosryhmillä oli yhteinen käsitys palvelun tavoitteista (Rabiee \& Glendinning 2011; Tinetti ym. 2012). Palvelun tarjoajien roolijakojen tuli olla myös selkeät (Tinetti ym. 2012). Vaarana oli, että palvelun piiriin ohjattiin asiakkaita, jotka eivät hyötyneet arkikuntoutuksesta, koska muita palveluita ei ollut saatavilla (Rabiee \& Glendinning 2011).

Arkikuntoutusta toteutettiin varhaisessa vaiheessa (Lewin \& Vandermeulen 2010; Lewin ym. 2013b) ja arkikuntoutuksessa huomioitiin tehokas resurssien käyttö (Langeland ym. 2015). Arkikuntoutusta kuvattiin perinteisiin kotihoitopalveluihin verrattuna dynaamisemmaksi prosessiksi, sillä arkikuntoutus oli lyhyt, tavoitekeskeinen, joustava ja kohdennettu interventio, jossa kotikäyntien sisältöä ja toteutusta voitiin muuttaa nopeasti asiakkaan toimintakyvyn mukaan. Lisäksi arkikuntoutuksen käyntien ajoitus sekä kesto olivat joustavampia kuin tavanomaisessa kotihoidossa. (Rabiee \& Glendinning 2011.) Arkikuntoutuksessa hyödynnettiin resurssipoolia ja paikallisia resursse- ja. Uusia työntekijöitä varten kirjattiin ohjeistus arkikuntoutuksen toteutuksesta. Arkikuntoutuksessa hyödynnettiin myös kasvotusten kohtaamisten vähentämistä käyttämällä puhelintukea ja puhelinseurantaa. (Lewin \& Vandermeulen 2010.)

Keskeinen osa arkikuntoutusta oli, että henkilökuntaa tuettiin olemaan luova, ratkaisemaan asiakkaan haasteita sekä tukemaan asiakkaan motivaatiota. Näiden toteutumista vaikeuttivat erityisesti esimiehiltä tulevat aikapaineet ja jos näiden toteutusta ei huomioitu käyntiajoissa. Jos arkikuntoutus toteutettiin muun palvelun yhteydessä eikä erillisenä palveluna, luovuuden toteutusta tuli erityisesti tukea joustavilla käyntiajoilla. (Rabiee \& Glendinning 2011.)

Henkilökuntaa koulutettiin tukemaan asiakasta terveelliseen ikääntymiseen, lääkkeiden käyttöön ja onnettomuuksien ehkäisyyn (Lewin \& Vandermeulen 2010). Arkikuntoutuksessa henkilökunta tarvitsee myös taitoja motivoida ja rohkaista palvelun käyttäjiä tulemaan mahdollisimman itsenäisiksi (Rabiee \& Glendinning 2011). Monitieteinen asiantuntijaryhmä kotihoidon asiantuntijoita tutustutti henkilökunnan asiakkaiden toimintakyvyn tukemiseen sekä kehitettyihin menetelmiin päivittäisten toimien arvioimiseksi ja muutoksen mittaamiseksi. Asiantuntijat painottivat henkilökuntaa keskittymään henkilökohtaisten toiminnallisten tavoitteiden kehittämiseen asiakkaan kanssa sekä yhdistämään arkkikuntoutus asiakkaiden tavoitteisiin. (Tinetti ym. 2012.) Henkilökunta korostikin alkuvaiheen arkikuntoutuskoulutuksen merkitystä sekä jatkuvaa koulutusta tiimikokouksissa sekä jatkuvaa valvontaa, jotta arkikuntoutuksen käyttö päivittäisessä käytössä vahvistuisi. Esimiehet seurasivat esimerkiksi kirjaamisen onnistumista. (Rabiee \& Glendinning 2011.) Arkikuntoutusjakson jälkeen asiakkaille, jotka tarvitsivat edelleen apua päivittäisissä toimissa (esim. peseytymisessä) tai välineellisissä päivittäisissä toimissa (esim. pyykinpesussa), tarjottiin tavanomaista kotihoidon palvelua (Lewin ym. 2013a), hei- 
dät ohjattiin hoidon koordinaattorille (Lewin \& Vandermeulen 2010; Lewin ym. 2013a) tai tuki järjestettiin jotenkin muulla tavoin (Lewin ym. 2013b).

Arkikuntoutus kesti niin kauan, että asiakas saavutti tavoitteet (Lewin \& Vandermeulen 2010; Lewin ym. 2013b) mutta kuitenkin enintään 12 viikkoa (Lewin \& Vandermeulen 2010; Lewin ym. 2013a; Lewin ym. 2013b; Tuntland ym. 2014; Hjelle ym. 2017). Arkikuntoutuksen kuvattiin kestävän keskimäärin 62 päivää (Lewin \& Vandermeulen 2010) tai 6 viikkoa (Rabiee \& Glendinning 2011; Whitehead ym. 2014). Lyhimmillään arkikuntoutus kesti kolme viikkoa (Langeland ym. 2015). Joillakin asiakkailla arkikuntoutus kesti pidempään kuin määritellyn maksimimäärän, kun heidän katsottiin etenevän hyvin tavoitteidensa saavuttamisessa, mutta asiakas tarvitsi edelleen jonkin verran tukea (Lewin \& Vandermeulen 2010; Rabiee \& Glendinning 2011). Myös jatkohoidon saamisen haasteet saattoivat olla syynä, että arkikuntoutusjakso jatkui yli maksimirajan (Rabiee \& Glendinning 2011; Whitehead ym. 2016). Useimmat ihmiset saavuttavat tavoitteensa hyvissä ajoin ennen 12 viikon takarajaa (Lewin \& Vandermeulen 2010). Hoitajan kontaktien määrä asiakkaaseen vaihteli päivittäisestä kontaktista joka toinen viikko toteutuvaan kontaktiin vähinään kahden viikon ajan (King ym. 2012). Arkikuntoutusta kuvattiinkin intensiiviseksi (Langeland ym. 2015) ja lyhytaikaiseksi (Rabiee \& Glendinning 2011a; Lewin ym. 2013a) palveluksi.

\section{Arkikuntoutuksen kohderyhmä}

Arkikuntoutuksen kohderyhmä määriteltiin iän, diagnoosin, toimintakyvyn ja palvelujen käytön avulla. Aikuisille suunnatun arkikuntoutuksen ikärajana määriteltiin, että arkikuntoutus suunnattiin ikääntyneille (Lewin ym. 2013a; Lewin ym. 2013b), yli 65-vuotiaille (King ym. 2012; Tinetti ym. 2012; Lewin ym. 2013a; Parsons ym. 2013) tai täysi-ikäisille (Rabiee \& Glendinning 2011; Tuntland ym. 2014; Whitehead ym. 2014; Langeland ym. 2015; Mann ym. 2016; Whitehead ym. 2016) asiakkaille. Diagnoosiin liittyviä tyypillisiä kriteereitä olivat, että asiakkaalla ei saanut olla diagnosoitua dementiaa (Lewin \& Vandermeulen 2010; Lewin ym. 2013a; Lewin ym. 2013b; Whitehead ym. 2014; Whitehead ym. 2016) tai vakavaa dementiaa (Rabiee \& Glendinning 2011).

Arkikuntoutus suunnattiin asiakkaille, jotka toimintakykynsä perusteella tarvitsivat henkilökohtaista hoitoa (Lewin ym. 2013a; Lewin ym. 2013b) tai apua yhdessä tai useammassa päivittäisessä toiminnossa (Lewin \& Vandermeulen 2010; Tuntland ym. 2014) pysyvän vamman vuoksi (Lewin ym. 2013b). Lisäksi perusteena saattoi olla, että asiakkaalla on uusia tai lisääntyviä haasteita päivittäisissä toimissa (Whitehead ym. 2016). Asiakkaalla ei saanut olla vakavia kognitiivisia häiriöitä (Tinetti ym. 2012; Parsons ym. 2013; Tuntland ym. 2014) ja asiakkaalla tuli olla kyky osallistua arkikuntoutukseen (Tinetti ym. 2012). Elämän loppuvaiheessa olevat asiakkaat rajattiin arkikuntoutuksen ulkopuolelle (Rabiee \& Glendinning 2011; Tuntland ym. 2014; Whitehead ym. 2014; Langeland ym. 2015; Whitehead ym. 2016). Rajallisten resurssien takia arvio asiakkaan toimintakyvyn kohenemisen mahdollisuuksista vaikutti arkikuntoutukseen pääsemiseen (Rabiee \& Glendinning 2011).

Asiakkaan palvelujen käyttö oli myös kriteerinä arkikuntoutuksen saamiselle. Arkikuntoutusta myönnettiin uusille kotihoidon asiakkaille (Lewin \&Vandermeulen 2010; Rabiee \& Glendinning 2011; Parsons ym. 2013), tai kun asiakas esimerkiksi saapui kotihoitoon akuutin sairaalajakson päätyttyä (Tinetti ym. 2012) tai kotiutui muusta syystä sairaalasta (Whitehead ym. 2016). Erityisesti asiakkaat, jotka lähtivät sairaalasta ja jotka todennäköisesti ohjattaisiin lisäpalvelujen piiriin, saivat arkikuntoutusta (Whitehead ym. 2016). Kotihoitoa hakeville asiakkaille myönnettiin myös arkikuntoutusta (Tuntland ym. 2014; Hjelle ym. 2017), ja lisäksi arkikuntoutusta saivat nykyiset kotihoi- 
don asiakkaat (Lewin \& Vandermeulen 2010; King ym. 2012; Tinetti ym. 2012; Tuntland ym. 2014; Whitehead ym. 2014), joiden palvelun määrää olisi tullut nostaa (Lewin \& Vandermeulen 2010). Arkikuntoutusta ei kuitenkaan myönnetty asiakkaille, jotka tarvitsivat ympärivuorokautista hoitoa (Tinetti ym. 2012), eikä asiakkaille, jotka saivat erityistä dementoituneille suunnattua kotiapua (Whitehead ym. 2014; Whitehead ym. 2016). Arkikuntoutusta ei myönnetty akuuttia eikä post-akuuttia apua (Lewin \& Vandermeulen 2010; Lewin ym. 2013b) tarvitseville eikä palliatiivista hoitoa (Lewin ym. 2013a; Lewin ym. 2013b) saaville asiakkaille. Arkikuntoutuksen saamisen kriteerinä oli myös, että asiakas asuu tietyn tyyppisessä palveluasumisen muodossa (Lewin ym. 2013a; Whitehead ym. 2014; Whitehead ym. 2016).

\section{Pohdinta}

Arkikuntoutuksessa oli keskeistä asiakkaan yksilöllisyyden huomiointi. Arkikuntoutus perustui asiakkaalle merkityksellisten arjen toimien määrittelyyn, ja asiakas arvotti itse hänelle tärkeät arjen toimet,joiden perusteella määriteltiin arkikuntoutuksen tavoitteet. Arkikuntoutuksen tavoitteet liittyivät asiakkaan toimintakykyyn sekä osallisuuteen ja aktiivisuuteen yhteiskunnassa. Arkikuntoutusjakson tavoitteena oli esimerkiksi voileivän tekeminen, asiointi tai harrastukseen meneminen. Arkikuntoutus toteutui asiakkaan omassa elinympäristössä, missä asiakas muutenkin liikkuu, kuten kotona, harrastuksissa tai asioilla. Kotona asuville arkikuntoutus oli varhaisen vaiheen tuki, jota tarjottiin asiakkaille, joilla oli yksi tai useampi toimintakyvyn rajoite. Arkikuntoutusta ei tarjottu asiakkaille, joilla oli diagnosoitu dementia.

Arkikuntoutuksessa käytettiin COPMtai TARGET-arviointimenetelmiä. Pohjoismaisissa tutkimuksissa suosittiin COPMarviointimenetelmää ja Uudessa-Seelannissa sekä Isossa-Britanniassa TARGET-arviointi- menetelmää. COPM-arviointimenetelmällä voitiin osoittaa arkikuntoutusjakson vaikuttavuus asiakkaan kokemana. Pohjoismaissa arkikuntoutusta toteutti moniammatillinen tiimi, johon kuuluu toiminta- ja fysioterapeutti, lähihoitaja ja sosiaalityön asiantuntija. Yhdysvalloissa ja Uudessa-Seelannissa arkikuntoutusta toteuttivat hoitajat, ja asiakkaat saivat nopeasti toiminta- ja fysioterapeutin ohjausta, mikäli tarvitsivat. Arkikuntoutuksessa käytettiin fyysistä toimintakykyä tukevia harjoitteita, päivittäisten toimien toistamista sekä toiminnan ja ympäristön muokkaamista. Arkikuntoutuksessa keskityttiin asiakkaan voimaantumisen tukemiseen ja vuorovaikutuksessa tuettiin asiakkaan varmuuden ja turvallisuuden tunnetta kannustavalla, arvostavalla ja itsenäisyyden tunnetta tukevalla puhetavalla. Kannustamisen onnistuminen edellytti työntekijöiltä huolellista kirjaamista, jotta työntekijät pystyivät seuraamaan asiakkaan edistymistä tarkasti ja osoittamaan muutokset asiakkaalle. Arkikuntoutuksessa työntekijöiden aikataulu oli joustava, jotta sisältöä ja toteutusta voitiin muuttaa nopeasti asiakkaan toimintakyvyn mukaan. Työntekijöitä tuettiin luoviin ratkaisuihin, minkä toteutuminen edellytti myös joustavaa aikataulua. Arkikuntoutus oli rajattu jakso ja kesti tyypillisesti 8-12 viikkoa. Arkikuntoutustiimin johtamisessa korostui selkeän työnjaon merkitys, jatkuva koulutus sekä tiimin yhteistyön toimivuuden varmistaminen.

Arkikuntoutuksen kuvaukset on koottu eri maissa toteutetuista tutkimuksista. Kuntoutuksen toteutuksessa sekä kuntoutusjärjestelmässä on eroja maiden välillä. Vaikka kaikki tutkimukset ovatkin länsimaista, herää kysymys, voidaanko arkikuntoutuksen ominaispiirteitä siirtää suoraan sellaisenaan suomalaiseen kuntoutusjärjestelmään. Kuntoutuksen ammattilaisten koulutuksissa on eroja maiden välillä, ja esimerkiksi Norjassa on sellaisia kuntoutuksen alan tutkintoja, joita Suomessa ei tarjota. Näin ollen arkikuntoutuksen järjestelmällinen toteuttaminen Suomessa vaatisi kuntoutuksen ammattilaisten koulutusten suunnitelmallista 
kehittämistä. Tutkimusten mukaisen arkikuntoutuksen toteuttaminen on kuitenkin mahdollista myös Suomessa ja osa ominaispiirteistä toteutuu jo nyt joissakin kotikuntoutusta tarjoavissa kunnissa.

\section{Luotettavuus}

Kirjallisuuskatsauksissa riskinä on, että tietoa kerätään valikoivasti ja tuloksia tulkitaan subjektiivisesti (Autti-Rämö ym. 2016, 91-107). Tämän katsauksen luotettavuutta tukee Joanna Briggs Collaboration (2018) laadunarviointikriteeristön mukaisesti, että tutkimuskysymys on esitetty selkeästi ja mukaanottokriteerit ovat perusteltuja tutkimuskysymyksen näkökulmasta. Kirjallisuushaku toteutettiin järjestelmällisesti ja kattavasti useasta tietokannasta ja lisäksi toteutettiin käsihaku. Katsaukseen valitut artikkelit on vertaisarvioitu ja julkaistu tieteellisissä lehdissä. (The Joanna Briggs Collaboration 2018.) Katsausta laadittaessa oltiin riippuvaisia siitä, miten hyvin interventio ja sen toteutusympäristö oli alkuperäisissä artikkeleissa kuvattu (ks. mm. Autti-Rämö ym. 2016). Kaikissa mukaan otetuissa artikkeleissa kuvattiin arkikuntoutusinterventioita, mutta kuvauksen laajuus ja laatu vaihteli, mikä heikentää tämän katsauksen laatua. Katsauksen eteneminen sekä synteesin toteutus on kuvattu siten, että katsaus voidaan toistaa tai päivittää toisen ryhmän toimesta (Autti-Rämö ym. 2016). Tulosten viitteet on esitetty lähdeviittauksina, jotta lukija voi tarkistaa niiden alkuperäistiedot (Varantola 2013, 12).

Kirjallisuushaussa käsitteiden reablement tai re-ablement tai restorative esiintyminen rajattiin otsikkoon tai abstraktiin, koska käsitettä restorative käytetään hyvin monissa yhteyksissä, ilman että artikkeli käsittelee arkikuntoutusta. Ratkaisu perustuu oletukseen, että mikäli artikkelissa käsitellään arkikuntoutukseksi määriteltävää kotikuntoutuksen muotoa, arkikuntoutusta kuvaava sana on mainittu joko artikkelin otsikossa tai abstraktissa. Reablement-käsitettä sen sijaan ei käytetä juuri muussa yhteydessä kuin arkikuntoutusta käsiteltäessä. Näin ollen olisi perusteltua, että reablement-käsitettä ei rajattaisi abstraktiin tai otsikkoon. Haun luotettavuuden tarkastamiseksi haku toteutettiin reablement tai re-ablement hakusanoilla rajattuna abstraktiin ja ilman rajausta ja havaittiin, että haun tuloksissa oli muutaman viitteen ero. Näin ollen on mahdollista, että hausta on rajautunut pois yksittäisiä arkikuntoutusta käsitteleviä tutkimuksia, mikä voi heikentää tulosten luotettavuutta. Aikaisempiin arkikuntoutustutkimuksia käsitteleviin kirjallisuuskatsauksiin verrattuna tähän katsaukseen on kuitenkin tavoitettu suurin osa kriteerit täyttävistä julkaisuista (Ryburn ym. 2009; Sims-Gould ym. 2017).

Haun ja synteesin toteutuksen jälkeen arkikuntoutustutkimuksia on tehty lisää ja julkaisuissa on käytetty arkikuntoutuksesta myös käsitteitä enablement, re-enablement sekä community rehabilitation. Kyseiset käsitteet ovat tulleet mukaan myös tietokantojen omiin hakusanoihin. Jatkotutkimusaiheena olisikin tarkastella, onko arkikuntoutuksen toteutuksen painopiste muuttunut käsitteen muuttumisen myötä vai onko käsitteen muuttumisella tavoiteltu arkikuntoutuksen toteutusta kuvaavampaa sanaa.

Kirjallisuushaun rajauksena oli, että julkaisu tulee olla kokonaan saatavilla tai hankittavissa Tampereen yliopiston tietokantojen tai yhteyksien kautta. Aineiston hakua tehtäessä kolme julkaisua jäi pois synteesivaiheesta tämän kriteerin vuoksi. Näistä kaksi julkaisua saatiin hankittua käsikirjoituksen loppuvaiheessa, kun synteesi oli jo toteutettu, ja yksi väitöskirja vuodelta 2007 jäi kokonaan saamatta. Kaksi myöhemmin saatua julkaisua vahvistavat tämän artikkelin tuloksia (Burton ym. 2013; Winkel ym. 2015). Toisessa julkaisussa korostui erityisesti toimintaterapeutin rooli osana arkikuntoutusta (Winkel ym. 2015). Toimintaterapeutin roolin merkitys tuli esille myös synteesiin valituissa artikkeleissa, mutta jos artikkeli olisi ollut mukana synteesissä, toimintaterapeutin 
roolia olisi pystytty kuvaamaan hieman monipuolisemmin tuloksissa. Tulosten luotettavuutta heikentää, että yhteen aihetta käsittelevään julkaisuun ei päästy tutustumaan tarkemmin. Tosin kyseinen julkaisu ei ollut mukana myöskään Sims-Gouldin ja kumppaneiden (2017) laatimassa arkikuntoutuksen toteutusten eroja arvioivassa katsauksessa. Tämän katsauksen tulokset ovat myös samansuuntaiset arkikuntoutusta kuvaavan aikaisemman kirjallisuuden kanssa (esim. Tuntland \& Ness 2014), joten voidaan arvioida, että julkaisujen pois jääminen ei muuta keskeisesti tuloksia.Julkaisujen avulla tuloksiin olisi todennäköisesti kuitenkin saatu monipuolisempaa kuvausta erityisesti arkikuntoutuksen keinoihin.

Kirjallisuuskatsauksessa varmistettiin, että julkaisu on vertaisarvioitu, mutta tutkimuksille ei toteutettu erillistä laadunarviointia. Käsitteen ominaispiirteitä määriteltäessä ei hyödynnetä varsinaisesti tehdyn tutkimuksen tuloksia,joten järjestelmällinen laadunarviointi ei ole merkityksellinen ja arvioinnin pois jättämisen ei nähdä heikentävän tutkimuksen tuloksia. Lisäksi kartoittavissa katsauksissa ei tyypillisesti toteuteta erillistä laadunarviointia (Levac ym. 2010).

Osassa mukaan valikoituneista artikkeleista arkikuntoutuksen ominaispiirteiden kuvaus oli rikkaampaa kuin toisissa. Joistakin artikkeleista löytyi useita samankaltaisia toisiaan tukevia kuvauksia, mutta lisäksi joistakin artikkeleista taas löytyi yksittäisiä muista poikkeavia ja muiden artikkeleiden kanssa ristiriitaisiakin $\mathrm{ku}-$ vauksia. Tuloksia ei arvotettu tutkijaryhmässä, vaan kaikki aineisto otettiin mukaan synteesiin ja esitettiin kootusti kirjallisuuskatsauksen tuloksissa. Tulosten viitetiedoista käy ilmi vastausten yleisyys aineistossa. Kirjoittajien katsauksen suorittamisen kannalta merkitykselliset sidonnaisuudet ilmoitetaan julkaisussa avoimuuden varmistamiseksi (Varantola 2013, 12). Arkikuntoutuksen kohderyhmän ominaispiirteitä tarkasteltaessa on huomioitava, että kirjallisuuskatsauksen sisäänottokriteereissä määriteltiin, että intervention kohderyhmä ei asu ympärivuorokautisessa hoidossa ja intervention kohderyhmänä ovat yli 65-vuotiaat. Rajaukset valittiin, koska lasten ja ympärivuorokautisen hoidon asiakkaiden arkikuntoutus eroaa tavoitteiltaan ja keinoiltaan monelta osin kotona asuvien aikuisten asiakkaiden arkikuntoutuksesta. Lisäksi aikaisemmissa tutkimuksissa arkikuntoutuksen suurin asiakasryhmä ovat olleet kotona asuvat ikääntyneet (esim. Kjerstad \& Tuntland 2015; Langeland ym. 2016).

Käsitteen ominaispiirteitä voidaan määritellä kirjallisuuskatsauksen lisäksi myös käsiteanalyysimenetelmin. Arkikuntoutuskäsitteen määrittely aloitettiin Walkerin ja kumppaneiden (1992) käsiteanalyysimenetelmän mukaisesti ja kirjallisuuskatsaus toteutettiin osana käsiteanalyysiä. Käsiteanalyysimenetelmän hyödyntäminen osoittautui kuitenkin haastavaksi, sillä ylä- ja lähikäsitteitä ei oltu määritelty täsmällisesti. Artikkelin johdonmukaisuuden takaamiseksi Walkerin ja kumppaneiden käsiteanalyysin vaiheet rajattiin pois julkaisusta. Arkikuntoutuksen suhde lähikäsitteisiin nähdäänkin tarpeellisena jatkotutkimusaiheena.

\section{Johtopäätökset}

Tämän kirjallisuuskatsauksen tuloksena määriteltiin arkikuntoutuksen ominaispiirteitä tavoitteiden, keinojen, organisoinnin sekä kohderyhmän näkökulmista. Arkikuntoutuksen tavoitteet liittyivät asiakkaan toimintakyvyn ja itsenäisen suoriutumisen tukemiseen, asiakkaan terveyttä edistävien ja sairauksia ehkäisevien taitojen kehittymiseen sekä asiakkaan osallisuuteen ja aktiivisuuteen. Arkikuntoutuksen toteutuksen keinoina hyödynnettiin yksilöllistä arkikuntoutusjakson toteutusta, asiakkaan voimaantumisen tukemista, asiakkaan toiminnan mahdollistamista sekä käytettäviä harjoitteita. Arkikuntoutuksen organisoinnissa ilmeni työnjakoon, johtamiseen ja kestoon liittyviä ominaispiirteitä, ja arkikuntoutuksen kohderyhmä määriteltiin iän, diagnoosin, toimintakyvyn sekä palvelujen käytön perusteella. 
Tulokset antavat uutta tietoa arkikuntoutuksen käytännön toteuttamisesta ja organisoinnista, mikä helpottaa arkikuntoutuksen käyttöön ottamista. Tulosten avulla alalla työskentelevät voivat verrata toteuttamaansa kotikuntoutusta arkikuntoutuksen ominaispiirteisiin ja tarkastella toteutusten eroja ja yhtäläisyyksiä. Vertailu tukee alalla toimivia toiminnan kehittämisessä. Tulokset tukevat alaa opiskelevia aiheen opiskelussa sekä opettajia aiheen opettamisessa. Arkikuntoutuksen ominaispiirteiden määrittely sujuvoittaa viestintää ja tukee yhteisen ymmärryksen saavuttamista

\section{Kirjallisuus}

\section{*Katsaukseen valitut artikkelit}

Autti-Rämö I, Salminen, A, Rajavaara M, Ylinen, A. Kuntoutuminen. 1. painos. Helsinki: Duodecim, 2016.

Boniface G, Mason, M, Macintyre J, Synan C, Riley J. The effectiveness of local authority social services' occupational therapy for older people in great britain: a critical literature review. Br J Occup Ther 2013;76(12):538-47.

https://doi.org/10.4276/03080221 3X13861576675240

Burton E, Lewin G, Boldy D. Barriers and motivators to being physically active for older home care clients. Phys Occup Ther Geriatr 2013;31(1):2136. https://doi.org/10.3109/02703181.2012.751474

Cochrane A, Furlong M, McGilloway S, Molloy DW, Stevenson M, Donnelly M. Time-limited home-care reablement services for maintaining and improving the functional independence of older adults. Cochrane Database Syst Rev 2016;10:CD010825.

https://doi.org/10.1002/14651858.cd010825. pub2

Gregory A, Mackintosh S, Kumar S, Grech C. Experiences of health care for older people who need support to live at home: a systematic review of the qualitative literature. Geriatr Nurs 2017;38(4):315-24.

https://doi.org/10.1016/j.gerinurse.2016.12.001
Suomessa kotikuntoutusmenetelmistä puhuttaessa. Lisätutkimusta tarvitaan muiden kotikuntoutusmuotojen ominaispiirteistä sekä arkikuntoutuksen suhteesta muihin kotikuntoutusmuotoihin.

\section{Yhteydenotto:}

Satu Niskanen, toimintaterapeutti, TtM, väitöskirjatutkija

Yhteiskuntatieteiden tiedekunta

Terveystieteet

Tampereen yliopisto

satu.niskanen@tuni.fi
*Hjelle KM, Tuntland H, Førland O, Alvsvåg H. Driving forces for home-based reablement; a qualitative study of older adults' experiences. Health Soc Care Community 2017;25(5):1581-9. https://doi.org/doi:10.1111/hsc.12324

Kääriäinen M, Lahtinen M. Systemaattinen kirjallisuuskatsaus tutkimustiedon jäsentäjänä. Hoitotiede 2006;18(1):37-45.

Khan K, Kunz R, Kleijnen J, Antes G. Systematic reviews to support evidence-based medicine: how to review and apply findings of healthcare research. London: Royal Society of Medicine Press, 2003.

*King AII, Parsons M, Robinson E, Jörgensen D. Assessing the impact of a restorative home care service in New Zealand: a cluster randomised controlled trial. Health Soc Care Community 2012;20(4):365-74.

https://doi.org/10.1111/j.13652524.2011.01039.x

Kjerstad E, Tuntland HK. Reablement in community-dwelling older adults: a cost-effectiveness analysis alongside a randomized controlled trial. Health Econ Rev 2015;6:15. https://doi.org/10.1186/s13561-016-0092-8

Kuntoutuksen uudistamiskomitean ehdotukset kuntoutusjärjestelmän uudistamiseksi. Sosiaali- ja terveysministeriö, 2017.

Kyngäs H, Elo S, Pölkki T, Kääriäinen M, Kanste O. Sisällönanalyysi suomalaisessa hoitotieteellisessä tutkimuksessa. Hoitotiede 2011;23(2):138-48. 
Langeland E, Førland O, Aas E, Birkeland A, Folkestad, B, Kjeken I ym. Modeller for hverdagsrehabilitering - en følgeevaluering i norske kommuner. Effekter for brukerne og gevinster for kommunene? Senter for omsorgsforskning, 2016.

*Langeland E, Tuntland H, Førland O, Aas E, Folkestad B, Jacobsen FF ym. Study protocol for a multicenter investigation of reablement in Norway. BMC Geriatr 2015;15:111. https://doi.org/10.1186/s12877-015-0108-y

Levac D, Colquhoun H, O’Brien KK. Scoping studies: advancing the methodology. Implement Sci 2010;5:69. https://doi.org/10.1186/1748-5908-5-69

*Lewin GF, Alfonso HS, Alan JJ. Evidence for the long term cost effectiveness of home care reablement programs. Clin Interv Aging 2013a;8:1273-81. https://doi.org/10.2147/CIA.S49164

*Lewin G, De SM, Knuiman M, Alan J, Boldy D, Hendrie D ym. A randomised controlled trial of the Home Independence Program, an Australian restorative home-care programme for older adults. Health Soc Care Community 2013b;21(1):69-78.

https://doi.org/10.1111/j.13652524.2012.01088.x

*Lewin G, Vandermeulen S. A non-randomised controlled trial of the Home Independence program (HIP): an Australian restorative programme for older home-care clients. Health \& Social Care in the Community 2010;18(1):91-9.

https://doi.org/10.1111/j.1365-

2524.2009.00878.x

*Mann R, Beresford B, Parker G, Rabiee P, Weatherly $\mathrm{H}$, Faria $\mathrm{R}$ ym. Models of reablement evaluation (MoRE): a study protocol of a quasi-experimental mixed methods evaluation of reablement services in England. BMC Health Serv Res 2016;16:375. https://doi.org/10.1186/s12913-016-1600-6

McGoldrick C, Barrett GA, Cook I. Befriending and re-ablement service: a better alternative in an age of austerity. Int J Sociol Soc Policy 2017;37(1/2):51-68. https://doi.org/10.1108/IJSSP-08-2015-0090

*Parsons JGM, Sheridan N, Rouse P, Robinson E, Connolly M. A randomized controlled trial to determine the effect of a model of restorative home care on physical function and social support among older people. Arch Phys Med Reha- bil 2013;94(6):1015-22.

https://doi.org/10.1016/j.apmr.2013.02.003

Pettersson C, Iwarsson S. Evidence-based interventions involving occupational therapists are needed in re-ablement for older community-living people: a systematic review. Br J Occup Ther 2017;80(5):273-85.

https://doi.org/10.1177/0308022617691537

Petticrew M. Systematic reviews from astronomy to zoology: myths and misconceptions. BMJ 2001;322:98.

https://doi.org/10.1136/bmj.322.7278.98

*Rabiee P, Glendinning C. Organisation and delivery of home care re-ablement: what makes a difference? Health Soc Care Community 2011;19(5):495-503.

https://doi.org/10.1111/j.1365-

2524.2011.01010.x

Ryburn B, Wells Y, Foreman P. Enabling independence: restorative approaches to home care provision for frail older adults. Health Soc Care Community 2009;17(3):225-34.

https://doi.org/10.1111/j.13652524.2008.00809.x

Sims-Gould J, Tong CE, Wallis-Mayer L, Ashe MC. Reablement, reactivation, rehabilitation and restorative interventions with older adults in receipt of home care: a systematic review. J Am Med Dir Assoc 2017;18(8):653-663. https://doi.org/10.1016/j.jamda.2016.12.070

The Joanna Briggs Collaboration. JBI: Arviointikriteerit järjestelmälliselle katsaukselle. 2018. Internet: https://www.hotus.fi/wp-content/uploads/2019/03/jbi-kriteerit-ja-selosteosa-jarjestelmallinen-katsaus-final.pdf (viitattu 31.7.2020).

*Tinetti ME, Charpentier P, Gottschalk M, Baker DI. Effect of a restorative model of posthospital home care on hospital readmissions. J Am Geriatr Soc 2012;60(8):1521-6. https://doi.org/10.1111/j.15325415.2012.04060.x

*Tuntland H, Espehaug B, Forland O, Hole AD, Kjerstad E, Kjeken I. Reablement in community-dwelling adults: study protocol for a randomised controlled trial. BMC Geriatr 2014;14:139.

https://doi.org/10.1186/1471-2318-14-139

Tuntland H, Ness NE. Hverdagsrehabilitering. 1. utgave, 1. opplag. Oslo: Gyldendal Akademisk, 2014. 
Varantola, K. (2013). Hyvä tieteellinen käytäntö ja sen loukkausepäilyjen käsitteleminen Suomessa: Tutkimuseettisen neuvottelukunnan ohje 2012. God vetenskaplig praxis och handläggning av misstankar om avvikelser från den i Finland: Forskningsetiska delegationens anvisningar 2012. Responsible conduct of research and procedures for handling allegations of misconduct in Finland: Guidelines of the Finnish Advisory Board on Research Integrity 2012. Helsinki: Tutkimuseettinen neuvottelukunta, 2013.

Walker, LO, Avant KC, Viitanen R. Teoria - avain hoitotyöhön. Helsinki: Sairaanhoitajien koulutussäätiö, 1992.

*Whitehead PJ, Drummond AER, Walker MF, Parry $\mathrm{RH}, \mathrm{McGeorge}$ ID, Latif Z. Occupational therapy in HomEcare re-ablement services (OTHERS): study protocol for a randomized controlled trial. Trials 2014;15:447.

https://doi.org/10.1186/1745-6215-15-447
*Whitehead PJ, Walker MF, Parry RH, Latif Z, McGeorge ID, Drummond AER. Occupational therapy in HomEcare re-ablement services (OTHERS): results of a feasibility randomised controlled trial. BMJ Open 2016;6:e011868. https://doi.org/10.1136/bmjopen-2016-011868 Whitehead PJ, Worthington EJ, Parry RH, Walker MF, Drummond AER. Interventions to reduce dependency in personal activities of daily living in community dwelling adults who use homecare services: a systematic review. Clin Rehabil 2015;29(11):1064-76. https://doi.org/10.1177\%2F0269215514564894

Winkel A, Langberg H, Wæhrens EE. Reablement in a community setting. Disabil Rehabil 2015;37(15):1347-52. https://doi.org/10.3109/09638288.2014.963707 